\title{
Interaction between a dimethylamino group and an electron-deficient alkene in ethyl (E)-2-cyano-3-(8-dimethylamino-1-naphthyl)propenoate
}

\author{
Paul C. Bell, Marie Drameh, Nicola Hanly and John D. Wallis
}

Acta Cryst. (2000). C56, 670-671

Copyright (C) International Union of Crystallography

Author(s) of this paper may load this reprint on their own web site or institutional repository provided that this cover page is retained. Republication of this article or its storage in electronic databases other than as specified above is not permitted without prior permission in writing from the IUCr.

For further information see http://journals.iucr.org/services/authorrights.html

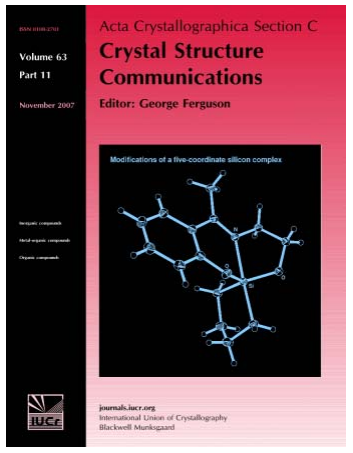

Acta Crystallographica Section C: Crystal Structure Communications specializes in the rapid dissemination of high-quality studies of crystal and molecular structures of interest in fields such as chemistry, biochemistry, mineralogy, pharmacology, physics and materials science. The numerical and text descriptions of each structure are submitted to the journal electronically as a Crystallographic Information File (CIF) and are checked and typeset automatically prior to peer review. The journal is well known for its high standards of structural reliability and presentation. Section $C$ publishes approximately 1000 structures per year; readers have access to an archive that includes high-quality structural data for over 10000 compounds.

Crystallography Journals Online is available from journals.iucr.org 
Acta Crystallographica Section C

Crystal Structure

Communications

ISSN 0108-2701

\section{Interaction between a dimethylamino group and an electron-deficient alkene in ethyl $(E)$-2-cyano-3-(8-dimethyl- amino-1-naphthyl)propenoate}

\author{
Paul C. Bell, Marie Drameh, Nicola Hanly and John D. \\ Wallis*t
}

Centre for Materials Research, School of Physical Sciences, University of Kent, Canterbury CT2 7NH, England

Correspondence e-mail: john.wallis@ntu.ac.uk

Received 30 November 1999

Accepted 10 January 2000

The interaction between the peri substituents in the title compound, $\mathrm{C}_{18} \mathrm{H}_{18} \mathrm{~N}_{2} \mathrm{O}_{2}$, measured at $150 \mathrm{~K}$, represents an early stage in the addition reaction of an amino group to an electron-deficient alkene, and has an $\mathrm{N}$. . C sp $p^{2}$ separation of 2.531 (2) $\AA$; comparison with related structures indicates that the nitrile group activates an alkene to nucleophilic attack more than a coplanar carboxylic ester group.

\section{Comment}

Studies of interactions between closely placed functional groups have been used to model the progress of the corresponding chemical reactions. Particular success has been obtained for addition of an amino group to a carbonyl bond, for which a variety of compounds model different stages in the reaction (Bürgi et al., 1973; Schweizer et al., 1978). Recently, we extended this approach to examine the Michael reaction between an amino group and an electron-deficient alkene (Bell \& Wallis, 1999) using the peri-substituted naphthalene derivatives (I)-(III). These compounds showed different degrees of $\mathrm{N}$. . C $s p^{2}$ interaction. Compound (I) has a structure much nearer to the zwitterionic enolate (IV) with an $\mathrm{Me}_{2} \mathrm{~N}-$ $\mathrm{C}\left(\mathrm{CX}_{2}\right)$ bond length of 1.651 (3) $\AA$ while compounds (II) and (III) show $\mathrm{Me}_{2} \mathrm{~N} \cdots \mathrm{C}=\mathrm{C} X_{2}$ separations of 2.413 (2) and 2.679 (2) $\AA$, respectively. The theoretical axis of the N atom's lone pair lies at a smaller angle to the N. . C interaction vector in (II) $\left(\mathrm{ca} 13^{\circ}\right)$ than in (III) $\left(\mathrm{ca} \mathrm{30^{ \circ }}\right)$. To extend these studies we have prepared the analogous compound (V) which was isolated as the only product of the Knoevenagel condensation of ethyl cyanoacetate and 8-dimethylaminonaphthalene-1carbaldehyde. To determine the stereochemistry of this alkene and to compare the interaction between the peri-substituents with those in (I)-(III), the structure of (V) has been determined by X-ray diffraction at $150 \mathrm{~K}$.

$\dagger$ Present address: Department of Chemistry and Physics, The Nottingham Trent University, Clifton Lane, Nottingham NG11 8NS, England.
The molecular structure of (V) is shown in Fig. 1 and selected geometric data are given in Tables 1 and 2. The stereochemistry about the double bond puts the less bulky nitrile group cis to the naphthalene ring. In contrast to the two carbonyl groups of derivative (III), the carboxy group of (V)

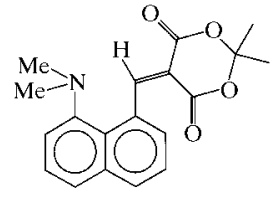

(I)

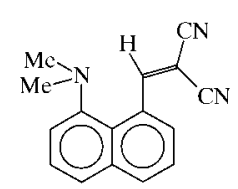

(II)

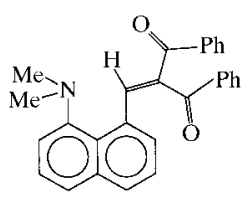

(III)

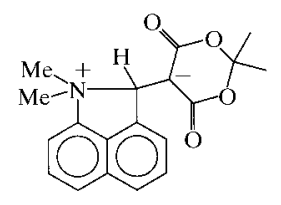

(IV)

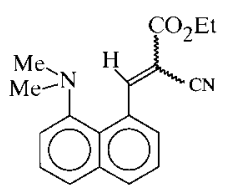

(V) lies nearly coplanar with the alkene $[\mathrm{O} 1-\mathrm{C} 14-\mathrm{C} 12-\mathrm{C} 13$ 5.5 (3), O2-C14-C12-C11 $9.4(3)^{\circ}$ ]. The best plane of the cyanoethenoate residue $(\mathrm{C} 11, \mathrm{C} 12, \mathrm{C} 13, \mathrm{C} 14, \mathrm{~N} 2, \mathrm{O} 1, \mathrm{O} 2)$ lies at $64.8(1)^{\circ}$ to that of the naphthalene ring. The dimethylamino group is oriented so that the $\mathrm{N}$ atom's lone pair is directed towards the other peri substituent. The shortest contact between peri groups is between the two atoms directly attached to the naphthalene skeleton; the N1..C11 separation is 2.531 (2) $\AA$, $c a 0.7 \AA$ within the sum of the van der Waals radii of $\mathrm{C}$ and $\mathrm{N}$ atoms. The interaction mimics an early stage in the Michael reaction between an amino group and an electron-deficient alkene. The two substituents are displaced slightly to opposite sides of the best naphthalene plane [N1 by 0.083 (2), C11 by 0.140 (2) $\AA$ ] and the angle between the $\mathrm{N} 1 \cdots \mathrm{C} 11$ vector and the alkene bond is $114.36(12)^{\circ}$. In the plane of the naphthalene ring the dimethylamino group is displaced from its theoretical position by $3.2^{\circ}$ towards the

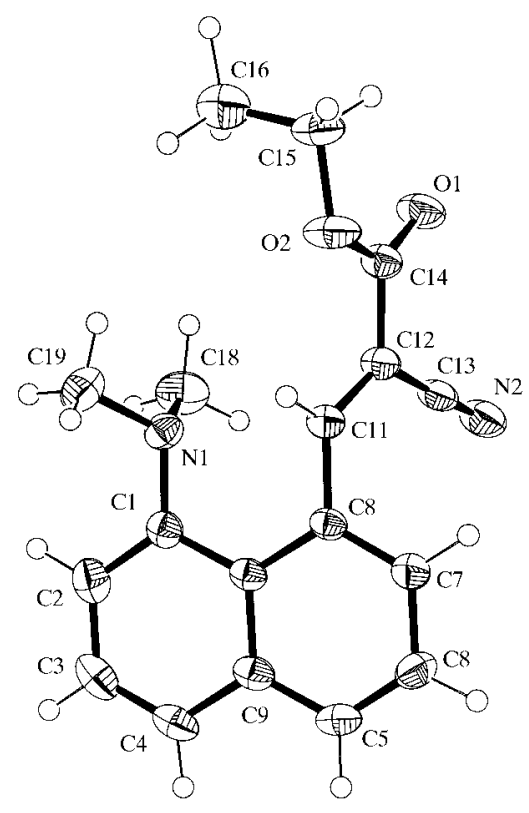

Figure 1

ORTEPIII (Johnson \& Burnett, 1996) drawing of the title compound with anisotropic displacement parameters drawn at the $50 \%$ level. 
alkene which is displaced away by $1.5^{\circ}$ in the same sense. The theoretical position of the amino $\mathrm{N}$ atom's lone pair axis lies at $18^{\circ}$ to the N1...C11 vector. There are no significant short intermolecular contacts consistent with the low density of the crystal.

The molecular geometry of compound (V) is intermediate between those of compounds (II) and (III) as illustrated by a variety of geometric parameters (Table 2) including the $\mathrm{N} 1$...C11 separation, the alkene bond length and the in-plane displacements of the peri functional groups. However in one respect, structure (V) is much closer to that of (II); the axes of the $\mathrm{N}$ atoms' lone pairs are both fairly closely aligned with the $\mathrm{N} 1$...C11 vector, and consistent with a weak bonding interaction between the functional groups. In contrast the alignment in (III) is much poorer.

The structural measurements on (II) and (V) which differ only in the replacement of a nitrile group with a carboxylic ester afford a comparison of the effects of the electron-withdrawing capacities of these groups on the reactivity of an alkene bond to nucleophiles. The nitrile group appears to be the superior since the interaction between the dimethylamino group and the alkene progresses further along the reaction coordinate for the Michael reaction in dinitrile (II) than in cyanocarboxylate $(\mathrm{V})$. The same trend is indicated by Hammett substituent parameters $\sigma_{I}, \sigma_{R}$ and $\sigma^{-}$for these substituents (Page \& Williams, 1997), though these are derived from aromatic systems.

\section{Experimental}

Substance (V) was prepared by refluxing 8-dimethylaminonaphthalene-1-carbaldehyde $(0.5 \mathrm{~g}, 2.5 \mathrm{mmol})$, ethyl cyanoacetate $(0.68 \mathrm{~g}, 6 \mathrm{mmol})$, benzoic acid $(0.2 \mathrm{~g})$ and piperidine $(2 \mathrm{ml})$ in toluene $(50 \mathrm{ml})$ using a Dean Stark apparatus for $24 \mathrm{~h}$. After extraction with aqueous sodium hydrogen carbonate and water, drying with sodium sulfate and evaporation, the residue was purified by chromatography on silica eluting with a 2:1 mixture of hexane and ethyl acetate to give (V) $(0.24$ g, 32\%, m.p. 335-337 K).

$$
\begin{aligned}
& \text { Crystal data } \\
& \mathrm{C}_{18} \mathrm{H}_{18} \mathrm{~N}_{2} \mathrm{O}_{2} \\
& M_{r}=294.34 \\
& \text { Triclinic, } P \overline{1} \\
& a=8.3856(4) \AA \\
& b=9.7270(4) \AA \\
& c=11.1860(5) \AA \\
& \alpha=69.274(3)^{\circ} \\
& \beta=68.037(3)^{\circ} \\
& \gamma=70.933(3)^{\circ} \\
& V=771.31(6) \AA^{3}
\end{aligned}
$$

$$
\begin{aligned}
& Z=2 \\
& D_{x}=1.267 \mathrm{Mg} \mathrm{m}^{-3} \\
& \text { Mo } K \alpha \text { radiation } \\
& \text { Cell parameters from } 11581 \\
& \quad \text { reflections } \\
& \theta=2.64-23.65^{\circ} \\
& \mu=0.084 \mathrm{~mm}^{-1} \\
& T=150(2) \mathrm{K} \\
& \text { Plate, yellow } \\
& 0.3 \times 0.3 \times 0.1 \mathrm{~mm}
\end{aligned}
$$

Table 1

Selected geometric parameters $\left(\AA{ }^{\circ}\right)$.

\begin{tabular}{llll}
\hline $\mathrm{O} 1-\mathrm{C} 14$ & $1.198(2)$ & $\mathrm{N} 1-\mathrm{C} 18$ & $1.459(2)$ \\
$\mathrm{O} 2-\mathrm{C} 14$ & $1.328(2)$ & $\mathrm{N} 1-\mathrm{C} 19$ & $1.459(2)$ \\
$\mathrm{O} 2-\mathrm{C} 15$ & $1.457(2)$ & $\mathrm{N} 2-\mathrm{C} 13$ & $1.143(2)$ \\
$\mathrm{N} 1-\mathrm{C} 1$ & $1.432(2)$ & & \\
$\mathrm{C} 14-\mathrm{O} 2-\mathrm{C} 15$ & $116.55(14)$ & $\mathrm{N} 2-\mathrm{C} 13-\mathrm{C} 12$ & $178.6(2)$ \\
$\mathrm{C} 1-\mathrm{N} 1-\mathrm{C} 18$ & $112.84(14)$ & $\mathrm{O} 1-\mathrm{C} 14-\mathrm{O} 2$ & $124.3(2)$ \\
$\mathrm{C} 1-\mathrm{N} 1-\mathrm{C} 19$ & $114.89(15)$ & $\mathrm{O} 1-\mathrm{C} 14-\mathrm{C} 12$ & $123.8(2)$ \\
$\mathrm{C} 18-\mathrm{N} 1-\mathrm{C} 19$ & $112.5(2)$ & $\mathrm{O} 2-\mathrm{C} 14-\mathrm{C} 12$ & $111.91(14)$ \\
\hline
\end{tabular}

\section{Data collection}

Enraf-Nonius KappaCCD areadetector diffractometer $\varphi$ and $\omega$ scans to fill Ewald sphere Absorption correction: multi-scan using multiple and symmetryrelated data measurements via SORTAV (Blessing, 1995)

\section{Refinement}

$R\left[F^{2}>2 \sigma\left(F^{2}\right)\right]=0.053$

$w R\left(F^{2}\right)=0.158$

$S=1.064$

2939 reflections

272 parameters

All $\mathrm{H}$-atom parameters refined $T_{\min }=0.912, T_{\max }=0.992$

Refinement on $F^{2}$
11581 measured reflections 3134 independent reflections 2461 reflections with $I>2 \sigma(I)$

$R_{\text {int }}=0.047$

$\theta_{\text {max }}=26.35^{\circ}$

$h=-10 \rightarrow 10$

$k=-12 \rightarrow 12$

$l=-13 \rightarrow 13$
Table 2

Selected molecular geometry $\left(\AA,^{\circ}\right)$ for compounds (II), (III) and (V).

\begin{tabular}{lrrr}
\hline & $(\mathrm{II})$ & \multicolumn{1}{c}{$(\mathrm{III})$} & \multicolumn{1}{c}{$(\mathrm{V})$} \\
\hline $\mathrm{N} 1 \cdots \mathrm{C} 11$ & $2.413(2)$ & $2.679(2)$ & $2.531(2)$ \\
$\mathrm{C} 11-\mathrm{C} 12$ & $1.354(2)$ & $1.341(2)$ & $1.346(2)$ \\
& & & \\
$\mathrm{N} 1-\mathrm{C} 1-\mathrm{C} 2$ & $124.3(2)$ & $122.3(2)$ & $123.3(2)$ \\
$\mathrm{N} 1-\mathrm{C} 1-\mathrm{C} 10$ & $115.9(1)$ & $118.3(2)$ & $116.8(1)$ \\
$\mathrm{C} 1-\mathrm{C} 10-\mathrm{C} 8$ & $120.4(1)$ & $123.5(2)$ & $122.4(1)$ \\
$\mathrm{C} 10-\mathrm{C} 8-\mathrm{C} 11$ & $120.2(1)$ & $122.5(2)$ & $121.7(1)$ \\
$\mathrm{C} 7-\mathrm{C} 8-\mathrm{C} 11$ & $120.3(1)$ & $117.6(2)$ & $118.6(2)$ \\
$\mathrm{N} 1-\mathrm{C} 11-\mathrm{C} 12$ & $112.5(1)$ & $118.0(1)$ & $114.4(1)$ \\
$\mathrm{C} 18-\mathrm{N} 1-\mathrm{C} 1-\mathrm{C} 2$ & $-81.5(2)$ & $-105.0(2)$ & $-82.9(2)$ \\
$\mathrm{C} 19-\mathrm{N} 1-\mathrm{C} 1-\mathrm{C} 2$ & $49.2(2)$ & $25.9(3)$ & $47.9(2)$ \\
\hline
\end{tabular}

$\mathrm{H}$ atoms were located and refined. $\mathrm{C}-\mathrm{H}$ distances were in the range 0.92 (2)-1.08 (2) $\AA$.

Data collection, cell refinement and data reduction: DENZO (Otwinowski \& Minor, 1997) and COLLECT (Hooft, 1998); program(s) used to solve structure: SHELXS86 (Sheldrick, 1990); program(s) used to refine structure: SHELXL93 (Sheldrick, 1993); molecular graphics: ORTEPIII (Johnson \& Burnett, 1996); software used to prepare material for publication: SHELXL93.

We thank Professor M. B. Hursthouse and the EPSRC National X-ray crystallography service for a dataset, and the EPSRC for a studentship (PCB) and the University of Kent for support.

Supplementary data for this paper are available from the IUCr electronic archives (Reference: FG1575). Services for accessing these data are described at the back of the journal.

\section{References}

Bell, P. C. \& Wallis, J. D. (1999). J. Chem. Soc. Chem. Commun. pp. 257-258. Blessing, R. H. (1995). Acta Cryst. A51, 33-38.

Bürgi, H.-B., Dunitz, J. D. \& Schefter, E. (1973). J. Am. Chem. Soc. 95, 50655067.

Hooft, R. (1998). COLLECT. Nonius BV, Delft, The Netherlands.

Johnson, C. K. \& Burnett, M. N. (1996). ORTEPIII. Report ORNL-6895. Oak Ridge National Laboratory, Tennessee, USA.

Otwinowski, M. \& Minor, W. (1997). Methods Enzymol. 276, 307-326.

Page, M. \& Williams, A. (1997). Organic and Bio-organic Mechanisms, pp. 5562. Harlow, England: Longman.

Schweizer, W. B., Procter, G., Kaftory, M. \& Dunitz, J. D. (1978). Helv. Chim. Acta, 61, 2783-2808.

Sheldrick, G. M. (1990). Acta Cryst. A46, 467-473.

Sheldrick, G. M. (1993). SHELXL93. University of Göttingen, Germany. 